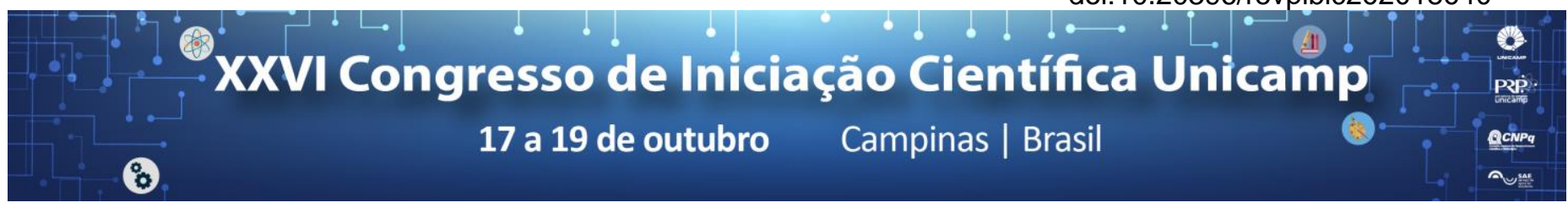

\title{
A Filosofia Humanista Cristã da Personagem Guilherme de Baskerville na Ficção de Umberto Eco
}

\section{Ivan L. V. Piffer, Marcos Aparecido Lopes}

\begin{abstract}
Resumo
Esta pesquisa se destina a investigar, no romance "O Nome da Rosa" do escritor italiano Umberto Eco, a personagem franciscana frei Guilherme de Baskerville e compreender seus traços que revelem um ideário humanista que dialoga com os valores do cristianismo. Baskerville sugere o aspecto moderno de que os indivíduos devem primar pela pluralidade de ideias e desenvolver seu espírito crítico, o que infere uma mensagem de Umberto Eco para o leitor da época contemporânea, a saber, proclamar a virtude da tolerância como um dos princípios fundamentais para nossa sociedade, sendo frei Guilherme o arauto do romancista.
\end{abstract}

\section{Palavras-chave:}

Literatura, Filosofia, Catolicismo.

\section{Introdução}

O enredo deste romance pós-moderno se passa no ano de 1327 em uma abadia localizada no norte da Itália, logo tem como contexto histórico o período de transição da Baixa Idade Média para a Idade Moderna. Nessa época a Igreja Católica possuía um amplo controle ético da consciência das pessoas, assim a influência teocêntrica ditava à sociedade os rumos que ela deveria seguir. Contudo, as perspectivas modernas de racionalismo, indagação e exaltação do ser humano começam a desabrochar no espírito dos pensadores, ameaçando a rigidez dogmática estabelecida.

Neste contexto, de acordo com os pressupostos da personagem de ficção de Candido (2005), analisamos a profundidade e a lógica delimitada de Guilherme de Baskerville para estabelecer uma relação dele com as perspectivas humanistas e os valores cristãos, além disso, investigamos sua performance a qual infere traços de Tolerância, pois a personagem contempla que a atitude do celestial para com todos os seus filhos é benévola, assim não há nada que justifique a violência do catolicismo para aqueles que seguem outras religiões, inferindo a frei Guilherme, portanto, um papel de herói da narrativa, aos moldes de Hamon (1976).

\section{Resultados e Discussão}

Para ilustrar no que concerne o Humanismo Cristão em nosso entendimento, podemos reunir as explicações de dois intelectuais. Desse modo, em uma perspectiva filosófica contemporânea, Said (2007) elucida o Humanismo como uma postura de reflexão da realidade, a qual se contrapõe a linguagem desprovida de senso crítico; já o coetâneo do medievo, Pico Della Mirandola (2006), explica que pela benevolência de Deus, o ser humano não foi enclausurado em si mesmo, mas agraciado com o livre arbítrio para lhe conferir liberdade de escolha. Esta exposição sintetiza os princípios de um humanismo em gestação que se interliga com o cristianismo.

As elucidações acima ao serem relacionadas com a totalidade da personagem Guilherme de Baskerville reconhecem que este ponto de vista é compartilhado por ele, uma vez que o frei se baseia no empírico e na crítica, porém, sem deslocar o sagrado de seu estatuto fundamental. Nesse sentido, Baskerville ainda ensina que o amor divino não possui barreiras e nem seletividade, assim como ressalta que nada fundamenta a postura violenta da Igreja para com aqueles que não seguem a religião de cristo. Isto posto, o justificamos como mensageiro da tolerância ao leitor hodierno.

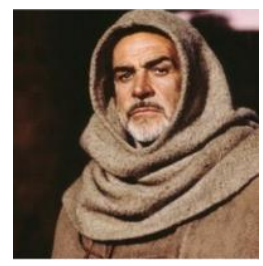

Figura 1. Sean Connery ao interpretar Guilherme de Baskerville no filme homônimo dirigido por Jean-Jacques Annaud.

\section{Conclusões}

A personagem em investigação representa as aspirações do novo homem humanista em uma relação dialógica com a moral cristã, pois ele traz para o âmbito da abadia o viés da renovação intelectual sob a luz da reflexão e da indagação, a fim de desvendar os mistérios desse mundo criado por Deus. Além disso, ele anuncia ao leitor o recado de Eco de enaltecer o respeito as diferentes religiões e filosofias, o que justifica o ideário da Tolerância como magna virtude.

\section{Agradecimentos}

Agradecemos ao Professor Doutor Marcos A. Lopes pela orientação no desenvolvimento do projeto e à mestranda Ana M. Cortes pelo auxílio nos momentos de dúvida. Expressamos gratidão ao Conselho Nacional de Desenvolvimento Científico e Tecnológico (CNPq) e ao Serviço de Apoio ao Estudante (SAE) pelo suporte financeiro essencial, sem o qual a pesquisa não poderia ser realizada com exclusividade de tempo.

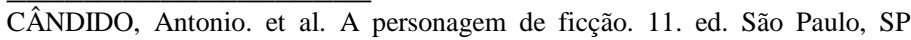
Perspectiva, 2005.

ECO, Umberto. O Nome da rosa; tradução de Aurora Fornoni Bernardini e Homero Freitas de Andrade- $6^{\circ}$ edição- Rio de Janeiro: BestBolso, 2016.

HAMON, Philippe. Para um estatuto semiológico da personagem. In: HAMON, Philippe e outros (orgs.). Categorias da narrativa. Trad. Fernando Cabral Martins. Lisboa: Vega Universidade, 1976, p.77-102.

PICO DELLA MIRANDOLA, Giovanni. Discurso sobre a dignidade do homem. Lisboa: Edições 70, 2006.

SAID, Edward. W. Humanismo e critica democrática. São Paulo, SP: Companhia das Letras, 2007. 